\title{
Symbolic potential of place and its modelling for management needs
}

\author{
Vytautas Petrušonis, Vilnius Gediminas Technical University
}

\begin{abstract}
Knowledge about the symbolic potential of the place (for example, city main square) and the form of presentation of such data is very important for better understanding of cultural memory of place. The article presents examples of symbolic potential descriptions of place using specific symbolic code sets. Code units consists from 1) names of identified easy recognizable objects forming a place and 2) cultural ideas, connotational characteristics of those objects. Some ideas appear as simple cultural connotations of certain objects and are easily identifiable. However, the fuller knowledge of local symbolic potential requires using of data that have more complex connotational structure. Such ideas encourage designers to comprehend the distinctive features of the place more deeply; also they are helping them to take into account personal existential experiences that are essential for the stimulating of original creative design solutions. Data about the place can help to manage it taking into account the symbolic potential only in case when the connotational characteristics are included into that data set. To ensure consensus among all relevant actors, data about place (city square, etc) expressed in codes with more complex connotational structures must be presented in explicit form (as some kind of semantic ,reference

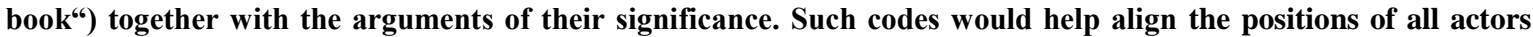
involved in the management of certain place. Codes of this kind need to be defined in advance by making the appropriate research activities before and included in the legal documents regulating place management. The article discloses the model of symbolic potential of Kaunas Unity Square (Vienybès aikštè) and its closest environment, formed in period after regaining independence in 1918. In order to protect ourselves from possible unscrupulous modernizations of square, we always have to take into account the symbolic potential of this place when planning even the smallest changes of square. Research of symbolic potential of the place was conducted using theoretical methods: abstraction, analogy, generalization, reasoning (inductive, deductive, and abductive), synthesis. Moreover, the methods of phenomenology and semantic analysis were applied also.
\end{abstract}

Keywords: cultural heritage protection, cultural memory of place, symbolic potential of place, cultural codes based on connotations, legal documents for the management of cultural areas

\section{Introduction}

Important data about the symbolic potential of the place and the way in which they are presented are important for a better understanding of cultural memory of Place. At the same time, such data are significant for the development of culture of poetic thinking, which is now recognized as an important factor in the activities related with reconstruction and renovation of the historically formed cities. According to M. Heidegger, in the context of European rationalism, the ideal of truth seeking was replaced by the scientistic ideal of analytic vivisection and rigor of logic: where technology becomes the means of "removing curtains from the secrets of existence," there, appears the individ who is not the „listener" of immanent and "secret" sound of Existence, but who is trying to set the norms, formulate detailed final definitions. Assuming that truth can be understood through language, Heidegger distinguishes another - a poetic language with which he is opposing to a language that is deformed by the logic. [8] Poetic thinking implies the abandonment of rigorous rationalism, and thus not only allows, but also leads to irrational (intuitive) thinking processes, where symbols take an important place [17].

Symbolic-poetic vision of the world is a specific way of knowing the world, which is also associated with mythological thinking. This way, which has an esoteric character (and is actively exploited in the culture of humanities - in phenomenology and hermeneutics), supplements the so-called scientific research methods, which are currently overemphasized and, due to that, there is a disproportion in the field of research, which makes the identity of the particular historical parts of the city inadequately investigated. J. Robinson characterized the current state of architecture research as one in which a dichotomous set of paradigms predominated. The terms by which she chooses to describe these two systems of inquiry are science and myth [12]. Although both science and myth "are used to explain," the way they do so is quite different. A scientific explanation is typically portrayed as a mathematical description made up of linked fragments; it is thereby atomistic, reductionist, and convergent [12]. These two groups of paradigms sometimes are discussed employng the terms quantitative versus qualitative [6].

Robinson scheme resembles the theory of famous mathematician egyptologist R. A. Schwaller de Lubicz where the field of research is divided in exoteric and the esoteric methods and means of interpretation [20]. Both access have to be coordinated because the are in relation of complementarity. 
Maybe, the most expressed esoteric moment is in the mythological world view. J. Lotman and B. Uspensky emphasize the imperative of interaction between the mythological and descriptive explanation [14]. What they call descriptive can be attributed to the "scientific" (J. Robinson) and also to the "exoteric" (R. Schwaller de Lubicz) way of representing and interpreting. A. Rappaport, who devoted a lot of attention to the architectural form, to the problems of architects creative thinking, as well differentiates scientific and mythological means, emphasizing their complementarity [18].

According V. Fedorov and I. Koval', symbols and myth are in close relation ("Any society has its own system of architectural symbols (ranging from historical monuments and temple complexes to typical national and regional landscapes), that organize and broadcast an emotionally-semantic experience (very often in the form of a myth") [19].

The symbols are actualising certain cultural archetypes. The archetypes are related to the process of transferring the socio-cultural memory. K. G. Jung uses the numinous concept helping understand the functioning of archetypes. The meaning of this word for the Romans corresponded to the meaning of the demon (in Greek). A demon is a deity coming from a supernatural environment and is more powerful than a simple person. Demons do not follow the categories of goodness and evil. In the Greek and Roman mythology, they simply descend into man and govern it as an alien, incomprehensible spirit. This is the power of archetypes. Their effect is numineous. Jung mentions examples when a thought, vision, dream, or inner voice comes to consciousness at appropriate time during a critical life moments and helps to make decision [9].

Acquainted with the publications of the last decade devoted to the cognition of the local cultural identity, for the understanding of genius loci, we can see that an esoteric moment, which is very important for creative solving the problems of urban renovation on instrumentual level factually is absent in reflections of specialists. The ignorance of esoteric research methods, their extremely limited use when trying to naively put them under the „umbrella“ of scientific research methods, impede the adequate use them in field of inquiry, as well as the proper organization of specialists education.

The aim of the article is to emphasize the importance of local symbolic potential for the management of the urban historical environment. The following tasks are planned: to study theoretical assumptions for the research of the symbolic potential of place, to offer the method for symbolic place potential description using specific symbolic code sets, to present examples of such description.

Research of symbolic potential of the place was conducted using theoretical methods: abstraction, analogy, generalization, reasoning (inductive, deductive, and abductive), synthesis. Moreover, the methods of phenomenology and semantic analysis were applied also.

\section{Theoretical assumptions for the research of the symbolic potential of place}

In talking about architectural symbols, usually the focus on purposefulness and intentionality is often too emphasized in the activities of architects and planners. Even the simplest buildings and structures architecture constantly and spontaneously create emotions and senses that are not always foreseen by its creators, because the meaning of the whole is always greater than the simple sum of the meanings of the elements. This meaning is always not only as an expression of people's livelihoods, but also as a factor in the reproduction and continuity of cultural capital, social ontology. Architecture is one of the incarnations of the spiritual experience of mankind, because everything, that a person creates, belongs to the cultural arsenal. But, even if we do not think (because we do not want or cannot) about the mythical - symbolic content of the architectural environment, it will not repeal the effect that inevitably manifests itself at the level of the subconscious.

We can only agree, when Fiodorov and Koval' are saying, that, impossible to accept the critics of contemporary city planning decisions, saying that "the city is purely functional objects that it has no symbolic load." Any architectural objects are full of symbolic content and are closely linked to the deep layers of human worldview, with his subconscious [19].

Architecture has the utilitarian side, but is also witnessing certain ideas, that are embodying a certain common ideology, for which the architect, according to Umberto Eco, belonged even before the starting of the project. He explains, that in the life of society, the symbolic meaning of architecture is not less utilitarian than its original purpose [21].

The urban environment embodying communication between subjectivities, at the same time also has a certain creative potential, because the true artwork necessarily brings something new to society, expresses itself as an aesthetic and symbolic message. It provides an interpretive reading that expands the informational possibilities. Architecture opens a new things to the degree to which it is able to use the secondary (symbolic) functions to promote new environmental organization variants, different expressions of the environment.

Of course, architecture is based on its own code, but at the same time it uses others that are not related to architecture directly. Namely they largely help to understand the meaning of the message. Information 
from the architectural text is perceived on such levels 1) the senses, 2) associations and images. The latter group includes emotional aesthetic and sociosymbolic aspects of human-architectural interaction.

Symbolic and aesthetic content encourages the creation of new items based on past experiences and real-life situations. It helps for people in the new light to see not only the perceived environment, but also the many aspects of their own being. An attempt to understand the meaning of the symbol, what Mamardashvili and Piatigorsky call "the field of symbol force", is often an excitation of a certain impulsive is often an excitation of a certain spontaneous impulse [16]. We can see here an analogy with the game. The competency of seeing, recognizing and understanding symbols only occurs when an individual has a high enough level of culture. The instinctive "sensation" of the symbol and conscious interpretation of the symbol are totally different things. The first thing, apparently, is get from nature, and the second is the result of conscious culture and long work In order to grasp what is symbolic, within the consciousness a defined "depth of the quality" is required. Primitive consciousness has a narrow spectrum of perception, it understands the world superficially. And the higher the qualitative level is achieved in the development of individual consciousness, the more it becomes sensitive to the symbol.

The symbol can not be deciphered by mental effort as it is in the case of an allegory. Semantic structure of symbol is multi-layered and understanding of it is predetermined by active internal work of perceptor. Through the immanent content of the symbol, the transcendental object is getting a new and later still newer direction. The only condition is "transparency" of the "immanent" content through which you can see the transcendental object. For the symbol to maintain this transparency, it does not need to be understood literally. According to Victor Frankl, only when the light of the intentional act is directed to the symbol, transcendence is manifested in it. With every new intentional act, the symbol is acquired and understood in a different new means. So, the symbol always remains in uncertaint state: it is always something less than an object that it symbolizes, but more than just its image. The meaning of the symbol objectively does not exist in static way, but as a dynamic trend; he is not given but is predetermined [5].

Karl Jung wrote that denying the enormous importance of symbols can only be the one for whom the beginning of the history of the world, is this day. If we recognize the importance of symbols, we give them the status of a conscious motive. It allows us to concentrate on helping the subconscious, looking for her connections with conscious mental work [22]. Symbols can be understood from the qualitative point of view, as images or signs of different types of psychological realities, as transformers of mental energy. Based on the fact that the main function of the symbol is the indirect representation of things that can not be communicated to people directly, R. Assagioli on lower-level distinguishes three functions of symbols: accumulation of mental energy, its transformation and transmission (symbols act as conductors or channels) [1].

Another important aspect is the effect of symbols on the subconsciousness, because communication with it on the logic language is not very effective. In addition, symbols are characterized by integrated action (they integrate the subconscious), they contribute to the unification of conscious and unconscious elements of personality. Many mental phenomena (in particular, altered states of consciousness) have a numinous property, that is, they are unintentional, induced by certain experience. According Jung, numinous is independent from will, it governs and controls a personal entity [9]. Numinous state can not be reached on will, you can only open yourself to it.

Unfortunately, in our time, symbols are usually understood as logical or pseudo-logical notions [19].

Understanding symbolic meanings allows a person not only to find new meanings, but also to unite and systematize his fragmented life experience. Knowledge of symbols encourages the formation of a personal relationship of individuum with symbols of perceived architectural environment and enriches his consciousness with new meanings. According the P. Ricoeur, the work of interpretation itself is to overcome the "cultural remoteness", the distance separating the individual from the text, which helps to turn the meaning of that text into the understanding of the present moment [11]. Therefore, the knowledge of symbols and the active focus on the symbol of a particular architectural environment are the basic conditions for the symbolism to be embodied in the individual's inner experience and to acquire the status of a personal property of the individual.

The operation with the symbol implies not the reconstruction of the denotation, but the understanding of the situation. Often, an individual does not realize that he is "in the field of the symbolic force" (in the sense of M. Mamardashvili and A. Piatigorsky [16]), and for this reason, the symbol does not become a conscious impulse to his activity [19]. In this case, the whole character of the symbol is limited to the subconscious level.

Human activity requires objective mediation using signs, symbols. It is supported by technical systems, objects of material culture, language, text systems, behind which there are various socio-cultural meanings. The multifaceted world of myths and human cultural symbols, which exists independently from the will and psychological characteristics of an individual, is precisely the "power" that determines and structures the activities of human thought. 
The symbol lies more than what he directly communicates to us, it posess the inherent inexhaustible multiplicity of content. Due to the fact that we have difficulty implying meaning of symbol, in most of us we interpret them too straightforwardly. By learning symbols, we at the same time capture part of his potential. This gives us the benefits of expanding the path to positive change. The expansion of consciousness takes place at the expense of the awakened and developed intuition resources, through the deliberate desire to master the skills of creative activity.

By creating an analogical, symbolic view of everything that happens in a city, mythical thought makes this a more easily comprehensible for us. That is why the cultural symbols and their configuration as certain myth of the city remains in the mass consciousness, along with the scientific elements of knowledge, influencing the behavior of the local community and the individual. The ability to recognize and understand the mythological symbolic meaning of architecture should become another way to better understand the world in which we live.

\section{Symbolic place potential presentment method using specific symbolic code sets}

The fact that we currently have problems with the perception of the importance of symbolic potential of place shows that the prevailing understanding of cultural heritage is limited. In that is trouble, because namely the symbols are important for cognition of place particuliarities. For the time being, architecturology and cultural heritage theory are dominated by the cultural heritage description categories that are more related to universal qualities of the heritage locality and of the objects found therein, and are actually dissociated from the specific cultural context, from an individual 'biography' of the object. The aforesaid characterisation of objects is grounded on the individual psychology categories that could not be related to the cultural context. For this reason, it is impossible to grasp the significance of cultural archetypes that arranges our perceptions and activities, and at the same time, hinder seeing of an importance of symbols and symbolic potential of the place.

In the Lithuanian legislation on cultural heritage protection, the value of objects that determines their protection is identified statically, in an absolute and contextually closed manner. Specific physical objects are often considered as certain qualities. An object may be a bearer of a certain quality, but it shall not be identified with the quality. Heritage descriptions contain practically no cultural ideas, connotative and denotative references are not adjusted either.
Unfortunately, foreign heritage descriptions contain practically no cultural ideas and cultural connotations as well. The aforesaid can be illustrated by the description of the residential house of Walter Gropius, one of the most prominent modernist architect, located in the USA (Gropius House National Historic Landmark Nomination)[7], and by the description of Casa Batlló, the building additionally attributed to the object 'Works of Antoni Gaudi' by the document of the World Heritage Committee) [3]. The main reason of this attitude towards the cultural heritage is a relict effect of the classical worldview. The principle of spatiality inherent in classical rationalism requires complete articulation of the matter outwards (available for external observation) as the condition of the things that could be generally known about the matter; as if the act of phenomena observation does not change the essence.

The solution grounded on abductive reasoning will be creative, however, only provided that the creator is able to use additional information on relevant 'mindful bodies'. According to $\mathrm{M}$. Mamardashvili, direct determination of thinking is impossible in the interrelationship between consciousness and being. It can be completed only through intermediary links and Mamardashvili was the first to call them 'mindful bodies' [15]. By the function, 'mindful bodies' are analogous to shifters known in linguistics, i.e. shifters are units the contents whereof is not important, however, the very units are significant for restructuring of perception. In the case under discussion, the function of shifters is carried out by the network of cultural ideas, symbols, connotations, cultural archetypes. Socially significant constructs, i.e. connotations as 'mindful bodies' or 'perception tools', may cover both symbols, metaphors and other conditionalized expert knowledge established in the process of any analysis of the object as well as carry out the function of mythological narratives important for communication of meanings. Hence, the valuable qualities of objects in descriptions should be listed along with the role of the object in the context (this is the thing represented by cultural ideas and connotations). For instance, in possession $\mathrm{P}$, preservation of a group of buildings as they are is desirable due to the following reasons (identifying certain cultural connotations): 1) they represent the industry specific to the region 2) they contribute to the urban development of the quay 3) height of the buildings enables to ensure historically significant visual relations, etc. Being sufficiently clear situationally, these characterisations capture the cultural memory. Such ideas are important to encourage architects to grasp better symbolic features of place, helping them more successfully take into account personal existential experiences 
that are essential for the development of original solutions.

In order to ensure consensus among all relevant actors, data of this type, expressed in codes with more complex cohesive symbolic structures, must be presented in an expanded form (explicitly). Such information would be helpful in the field of local design solutions, also and for justification of solutions. One way would be to supplement the current value descriptors with the connotations of the objects.

Code units proposed here consists from 1) names of identified easy recognizable objects forming a place and 2) cultural ideas, connotational characteristics of those objects. High-level professionals are usually able to operate with this kind of knowledge intuitively, but their communication with other persons, who are involved into the process of management of that territory due to their job functions but have lower level of competency, may be complicated. To ensure consensus among all relevant actors, data about place (city square, etc) expressed in codes with more complex connotational structures must be presented in explicit form (as some kind of semantic „reference book“) together with the arguments of their significance. Codes of this kind need to be defined in advance by making the appropriate research activities before and included in the legal documents regulating place management.

Descriptions combining denotative and connotative semantics (the latter is especially important for promoting creative thinking) might contribute to the existential experience actualisation of an architect for solving creative tasks as well as might play the role of a solution catalyst; informational support organised as mentioned above is the only way enabling the development of new original architectural pieces taking into account the social cultural memory.

\section{Examples of description: Symbolic potential of Vytautas Magnus Museum Complex in Kaunas Unity Square}

The example of Kaunas Vytautas Magnus Museum's complex of buildings and elements of garden related with them will show how to present the symbolic potential of the place using the connotational characterisation. Most symbols related to this place will be discussed, their position in the universe of Unity square symbols will be explained, and their symbolic and connotative meanings will be presented.

Originally Vytautas Magnus Museum was established in 1921 but later it was decided to move

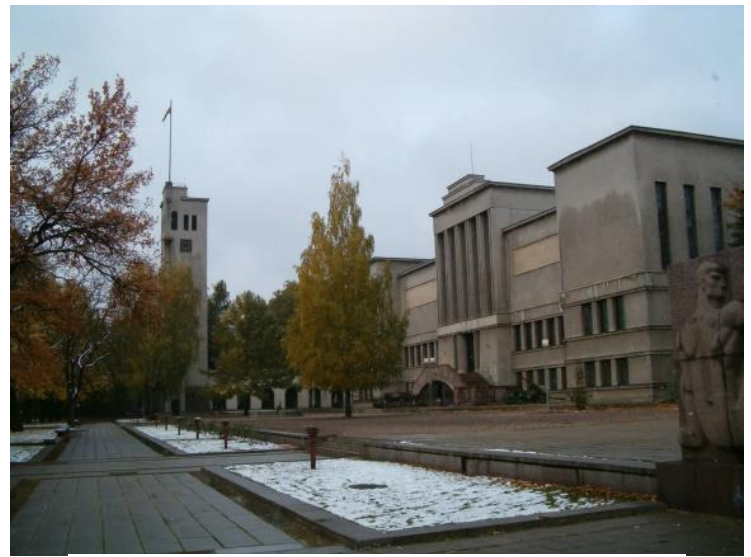

Fig 1. General view of western part of Unity squareMain palace of Vytautas Magnus musem and bell tover. Photo by the author, 2003.

to a larger location. A part of the new museum was opened in 1930, at the 500th anniversary of Vytautas the Great, Grand Duke of Lithuania, the namesake of the museum. In Figure 1, we see the west side of Unity Square.

As the basis for creating of the network of symbols, connotations let's use the metaphor 'Kauno Naujamiestis - Katedra' (Kaunas New Town Cathedral). Once, being in Laisvès alèja (Freedom Avenue), I felt that I solved of Kaunas's New Town's riddle: I recognized that Laisvès aleja, as well as Kęstutis and Donelaitis streets, are three naves of imaginable Cathedral basilica. Daukanto street embodies transept. A Sobor (St. Michael the Archangel Garrison Church, built in 19th century) serves as altar. It seems that Unity Square in this vision positioned in the northern end of 'transept' can be identified as chapel of heroes. This my accidental experience really was esoteric phenomenological insight.

Schematic representation of symbols groups related with cultural idea „The Cathedral“" we can see in Figure 2.

For a better understanding of the "The Cathedral" idea, let's take a look at the overall schematic picture of Kaunas's Naujamiestis (Kaunas New Sity) - Fig. 3.

In the following, we will examine in more detail the Vytautas Magnus Museum garden with memorial and symbolic monuments as important part of "Chapel of Heroes". For the tematical places and objects related with them look Figure 4.

Several tematical places and objects related with them are presented more detaily (Fig. 5, 6, 7).

I wrote earlier that in the environment of Unity Square, which includes the territory of the complex of Kaunas Vytautas Magnus Museum, significant societal cultural ideas are manifested. Among them - Idea of Unity and the abstract idea of symbolic totemic being Precursor [10]. Various objects in the territory of the complex of the museum and 


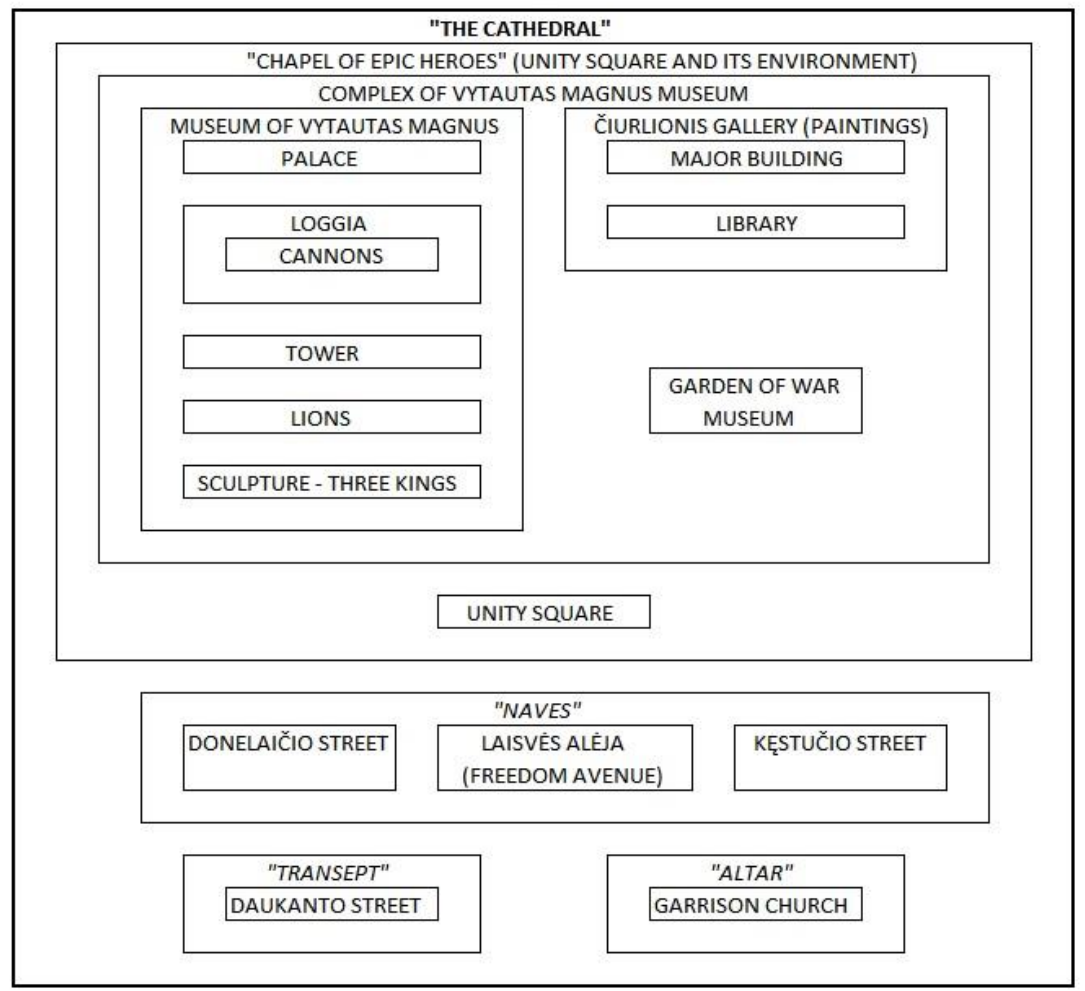

Fig. 2. Schematic representation of symbols groups related with cultural idea ,The Cathedral “

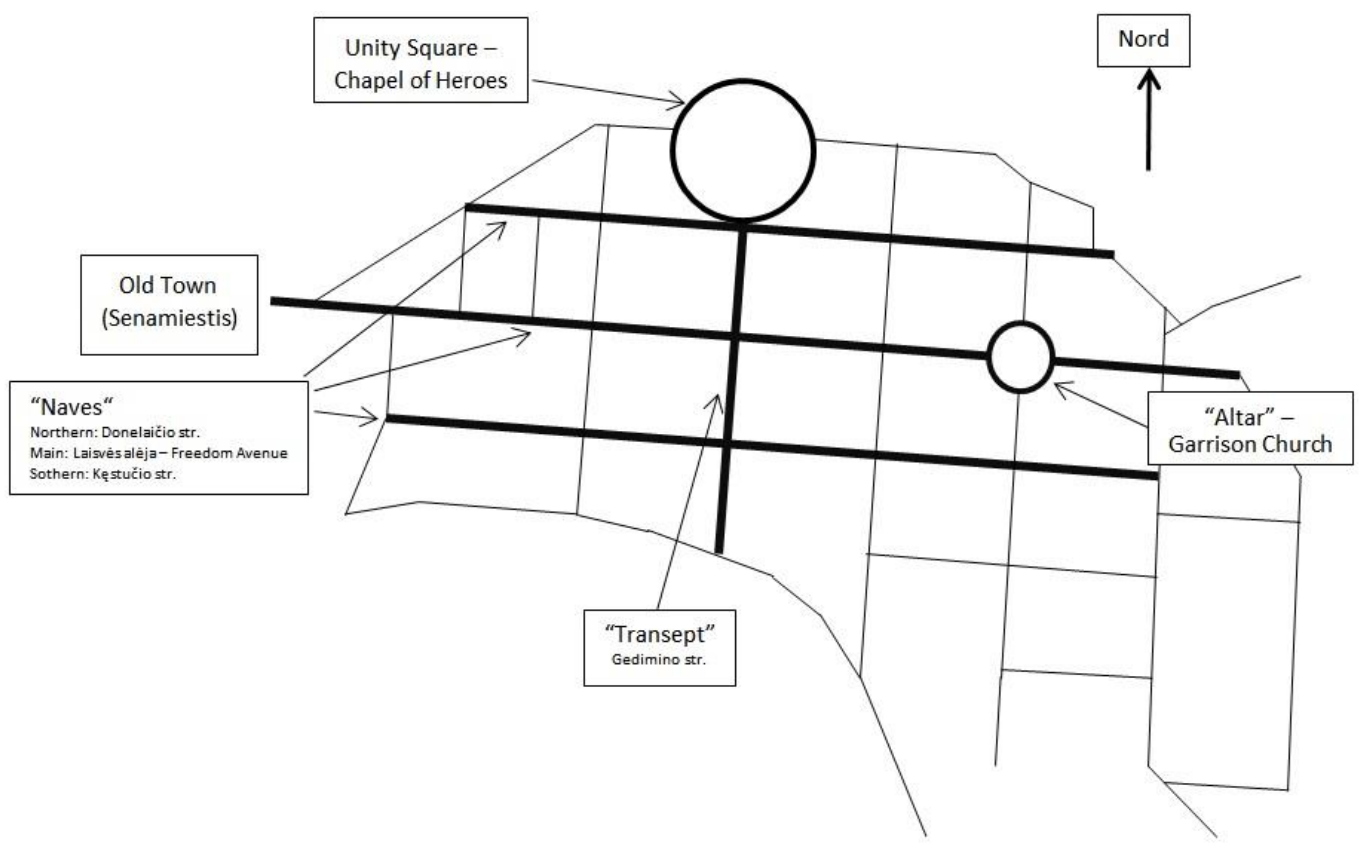

Fig. 3. The more general symbolic context: Kaunas Naujamiestis - "The Cathedral"

easily recognizable cultural connotations determines the expression of ideas of Unity and Precursor's. The Precursor is a totemic figure of a definite community, a collective cultural hero. Such person collective hero who is formed from many manifestations: semi-historical, semi-divine persons: priests, kings, soldiers, emperors, in general political and cultural figures. The location of the Precursor ussualy is in special sacred centers - mostly in the main squares of the capitals. The Precursor is inseparable from the certain genius loci.

His figure appears unwittingly in our consciousness by observing various signs that act as keys to hinting. The environment of the Vytautas Magnus Museum complex is very suitable for the recognizing, feeling of National Precursor person (here we are faced with a certain numinous effect). This place include hints, symptoms resembling 


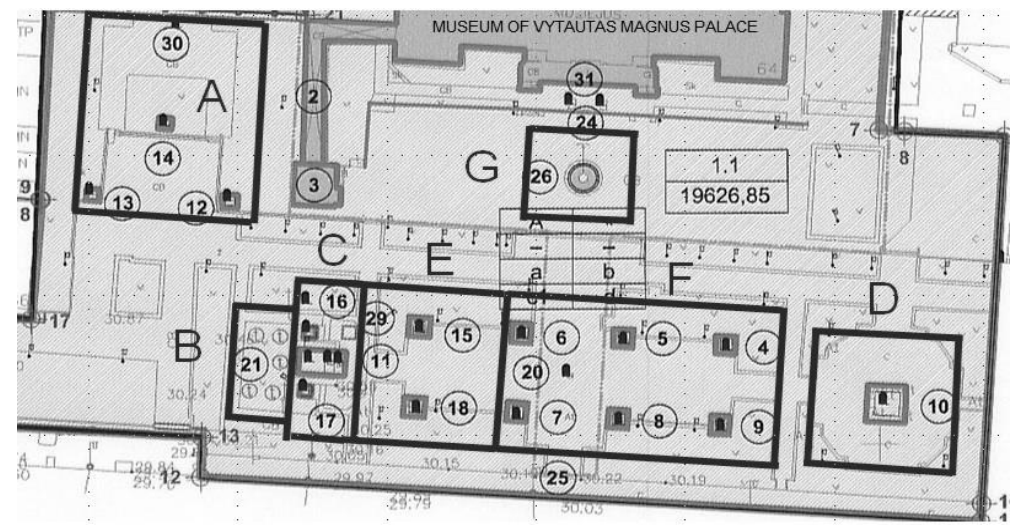

Fig. 4. Western part of Unity square (garden of Vytautas Magnus museum). Tematical places and objects related with them. Tematic places: $\boldsymbol{A}$-Place of appreciation for the nation's cultivation, $\boldsymbol{B}$-Place for Lithuania 's independence honouring, $\boldsymbol{C}$-Place for honouring of fallen war heroes, $\boldsymbol{D}$ - Freedom monument, $\boldsymbol{E}, \boldsymbol{F}$ - Nation's Fame Alley (E-Place for war heroes honouring, $\boldsymbol{F}$ Place for honouring of political and cultural celebrities - Lithuanian national renaissance figures), $\boldsymbol{G}$ - Fountain with statue of Gnome. Complex components (objects related with places; numbers taken from heritage management project [19]): 2. Loggia, 3. Carillon and clock tower, 4. Petras Vileišis monument, 5. Maironis monument, 6. Vincas Kudirka monument, 7. Jonas Basanavičius monument, 8. Simonas Daukantas monument, 9. Martynas Jankus monument, 10. Freedom monument, 11. Monument to the victims of Lithuanian freedom, Tomb of the Unknown Soldier, 12. Sculpture "Knygnešys " (The illegal book smuggler and spreader), 13. Sculpture "Sower", 14. Sculpture "School of Lithuania 1864-1904", 15. Vladas Putvinskis monument, 16. Povilas Lukšis monument, 17. Antanas Juozapavičius monument, 18. Silvestras Žukauskas monument, 20. Path-Nation's Fame Alley, 21. A group of wooden crosses, columns with a statuettes of a saints, 26. Fountain with Statue of Gnome, 29. Povilas Plechavičius monument, 30. Wall of illegal book spreaders, 31. Lion sculptures

Scheme of tematic places made by the author on map taken from heritage managemnet project [4].

significant episodes of history related to collective cultural heritage. When we contemplate them, the presence of Precursor in our conscious is guaranteed "here and now". An observer, even a casual visitor to Unity's Square, takes the position of an ancient priest entering into a polemic with chaos. Solving the „riddles“, experiencing the presence of Precursor manifested in different shapes (Precursor is both Maironis, Kudirka, Vytautas the Great and Kęstutis, and cannons taken from the enemies and testifying the heroism of volunteers; he also is and illegal book spreders, and the „Sower“", and historical the coats of arms on the tower), the visitor of the square is creating synthetic image of the Precursor, identifies himself with him.

Observing the Unity Square Ensemble, other city objects associated with Collective Precursor, the unexpected feeling of unity is emerging. It's like remembering. At such a moment, as if the spirit of the general Precursor resides in person. In Kaunas architecture, in its cultural topography, the theme of unity is expressed or encoded in various ways and degrees. In parts of the city's environment, it is expressed indirectly, while others are encoded in figurative. The theme of Unity is directly expressed in the name of Unity's Square.

The Garden of Vytautas Magnus Museum, located next to the Unity Square, can be considered as influenced by ideas of the Romanticism cemetery dedicated to meditation and having symbolic significance. There are all the signs of such cemetery: public figures, monuments to dead heroes, the Unknown soldier monument, and the eternal fire (such interpretation of meditation cemeteries is encouraged by J. Bialostock's ideas [2]) (C in Fig. 4 and 6).

In addition to the heroes' cemetery, in the Garden of Museum there are also signs that can be found in the folk village cemetery. They are embodied in wooden crosses, columns with a statuettes of a saints (B and 21 in Fig. 4). The researchers point out that in the 19th century and in the begining of 20th century rendering the images of vilage cemeteries in paintings, was typical of the nations that fought for independence [2].

In Garden the theme of unity is most prominently expressed by the eternal fire. It is known, that fire is as the paraphrase of the unity, Agni in Sanskrit means both Fire and Unity) [13]. The symbol of the Light (as other manifestation of eternal fire) on the square is activated by towers - ,obelisks“: the Freedom Monument (Fig. 7) and the bell tower of the museum (Fig. 1). M. Jampolsky, referring to A. Kircher and L. Bernini, argue that the obelisk "is the divine light falling on chaos" [23]. So, the Freedom Monument, the Tower of the Museum in this way are regenerating previously in Tsarist Russia times created territory of the Kaunas Center, which can be equated with "chaos".

The data presented in article discloses only part of the symbolic potential of Kaunas Vienybeis (Unity) Square and its closest environment. The Unity square was formed in period after regaining independence in 1918. The square in temporal capital of Lithuania in between war period was the place where the symbols of Lithuanian potential statehood have been erected (later demolished by soviets and finally re-erected after collapse of Soviet Union). In order to protect 


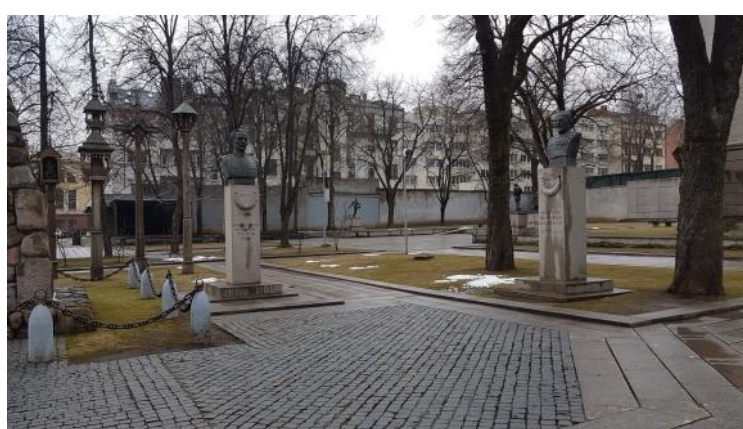

Fig. 5. C-Place for honouring of fallen war heroes (at left); A-Place of appreciation for the nation's cultivation:

12. Sculpture "Knygnešys" - The illegal book smuggler and spreader); 13. Sculpture "Sower";

14. Sculpture "School of Lithuania 1864-1904"; 30. Wall of illegal book spreaders. Photo by the author, 2018.

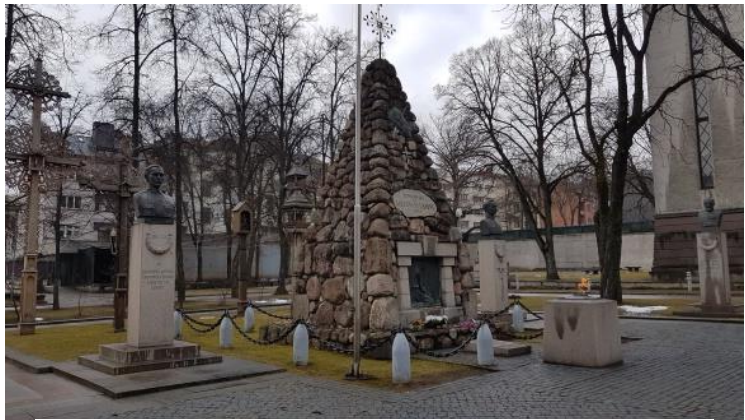

Fig. 6. B-Place for Lithuania 's independence honouring: 21. A group of wooden crosses, columns with a statuettes of a saints; , vilage cemetery“. $\boldsymbol{C}$-Place for honouring of fallen war heroes: 11. Monument to the victims of Lithuanian freedom, Tomb of the Unknown Soldier; 16. Povilas Lukšis monument; 17. Antanas Juozapavičius monument; 29. Povilas Plechavičius monument. Photo by the author, 2018.

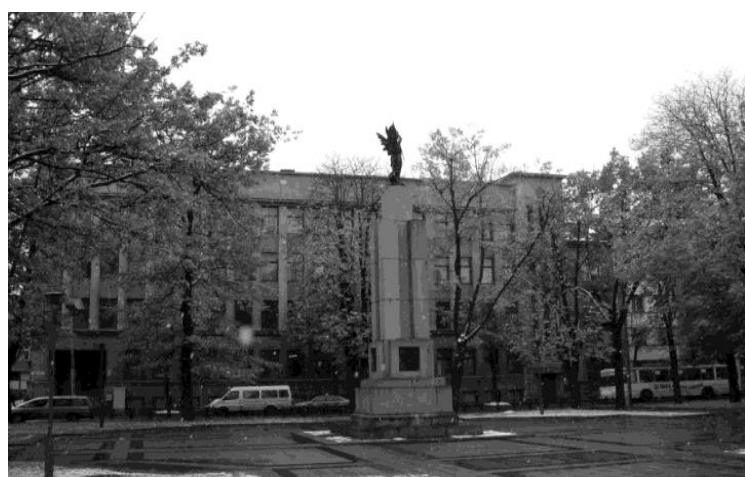

Fig. 7. D-Freedom monument. Photo by the author, 2003.

ourselves from possible unscrupulous modernizations of square, we always have to take into account the symbolic potential of this place when planning even the smallest changes of square.

The representation, description, presentment of symbolic potential on the base of semantic analysis can be equated to model. Semantic complexes „Unity“ and „Precursor“ presented here are overlapping. They both are working together. At the same time they are embodying an explicit form of semantic 'reference book'. The elements of model
- names of places, objects and connotations related with them are explained in article and justified theoretically. The main need is to use model of such kind because namely it can help to guarantee continuity of locus cultural identity in the territory management process, the continuation of symbolic potential of place as whole system.

\section{Conclusions}

1. Expressions of architectural forms, codes, also primary (denotational) and secondary (connotational) meanings create a certain meaningful universe. Recognition of such universe is important for the interpretation of architectural objects. Acquainted with the publications we can see that an esoteric moment, which is very important for creative solving the problems of urban renovation on instrumentual level and closely related with cognition of local symbols factually is absent in reflections of specialists. The ignorance of esoteric research methods, impede the adequate use them in field of inquiry, as well as the proper organization of specialists education. Human activity requires objective mediation using signs, symbols. It is supported by technical systems, objects of material culture, language, text systems, behind which there are various socio-cultural meanings. The multifaceted world of myths and human cultural symbols, which exists independently from the will and psychological characteristics of an individual, is precisely the "power" that determines and structures the activities of human thought.

2. To the understanding of the mythical-symbolic essence of the architectural environment is still not given the necessary attention. This plane of inquiry helps to join together different levels of reality mental and spatial. Most architectural elements do not require conscious identification - they appeal directly to the subconscious. Others act by activating symbols that control and direct our behavior and at the same time make sense to our lives. Due to the fact that we have difficulty implying meaning of symbol, we interpret them too straightforwardly.

3. By learning symbols, we at the same time capture part of his potential. This gives us the benefits of expanding the path to positive change. The expansion of consciousness takes place at the expense of the awakened and developed intuition resources, through the deliberate desire to master the skills of creative activity. By creating an analogical, symbolic view of everything that happens in a city, mythical thought makes this a more easily comprehensible for us. That is why the cultural symbols and their configuration as certain myth of the city remains in the mass consciousness, along with the scientific elements of knowledge, influencing the behavior of the local community and the individual. The ability to recognize and 
understand the mythological symbolic meaning of architecture should become another way to better understand the world in which we live.

4. To ensure consensus among all relevant actors, data about place (city square, etc) expressed in codes with more complex connotational structures must be presented in explicit form (as some kind of semantic „reference book") together with the arguments of their significance. Such codes would help align the positions of all actors involved in the management of certain place. Codes of this kind need to be defined in advance by making the appropriate research activities before and included in the legal documents regulating place management. The denotation and connotation characteristics must be combined in the knowledge presented in an explicit form. Delivering knowledge in an accessible form to all interested parties can guarantee the availability of information on the conditions for the implementation of the public interest

5. Unity Square and its environments (including Vytautas Magnus Museum, and its garden) in the center of Kaunas is a creature of an exceptional composition. Its authors are not just specific people. As authors can be understood those who in the third and fourth decades of 20th century, decided conceptually how the square should look, and those who created buildings, sculptures, planted the garden. Also we can name as authors those who even earlier and not even in no Lithuania, but influenced solutions in conceptual way. The Unity square is not a copyrighted work, it is rather a specific "folklore" text, transmitted from generation to generation, which plays an important role in upbringing of community.

6. Addressing to the characteristics of the city, presented here, opens new opportunities for better understanding of the monumental features of the objects of historically formed places. If accidental natural objects that correspond to the cosmological environment are protected, why do not protect complex of cultural objects that testify to the beginning of community. Even if they were formed maybe by chance, for example as the article mentioned the idea of Kaunas Naujamiestis as a „Cathedral“. When evaluating past monuments, we must take into account the role they play in capturing the specific "spirit" of the place, as they in their presence establish the world of ethically defined social harmony. The ethically defined condition of unity is possible only if the relations representing the unity of the square composition (or other sacred space, the same is true of the temples) are based not on the dominance of some subjectivities, but on the cooperation of subjectivities expressed in composition. This cooperation is the best gift for the ancient Precursor that symbolizes that unity.

7. In order to protect ourselves from possible unscrupulous modernizations of square, when we always have to take into account the symbolic potential of this place when planning even the smallest changes of square. Unfortunately, the description of Kaunas Vytautas Magnus Museum complex in the Register of Cultural Property is only a listing of objects. No cultural ideas, no cultural connotations. We can state, that ignorance of cultural ideas, cultural connotatons in representation of heritage objects is common place also and in other countries. The analysis of Walter Gropius house and Antonio Gaudi works collection description is witnessing that sad tendency.

References

1. Assagioli, R. Psychosynthesis: A Collection of Basic Writings. Amherst (USA): Synthesis Center, 2000. 287 p.

2. Bialostocki, J. Symbole i obrazy. Warszawa: PWN, Tom I, 1982. 506 p.

3. Convention Concerning the Protection of the World Cultural and Natural Heritage. Document WHC [-05/29. COM/8B. Paris, 15 June 2005. [online 22.05.2017], http://whc.unesco.org/en/sessions/29COM/documents.

4. Filipavičienè, G., Puodžiukaitè S. Kauno Vytauto Didžiojo muziejaus statinių kompleksas. Sprendiniai. Paveldotvarkos projektas. 2008.[online 22.07.2018], https://kvr.kpd.lt/\#/static-heritage-search

5. Frankl, V. Man's Search for Meaning. Boston: Beacon Press, 2006. 184 p.

6. Groat, L., Wang, D. Architectural research methods. 2nd ed. United States: John Wiley \& Sons, 2013. 468 p.

7. Gropius House NHL [National Historic Landmark] Nomination. NPS Form 10-900 USDI/NPS NRHP Registration Form (Rev. 8-86) OMB No. 1024-0018. Designated NHL May 16, 2000. United States Department of the Interior, National Park Service National Register of Historic Places Registration Form [online 22.05.2017]. https://www.nps. gov/nhl/find/statelists/ma/Gropius.pdf.

8. Heidegger, M. Poetry, Language, Thought. New York: Harper \& Row, 1971. 227 p.

9. Jung, C. G. A Psychological Approach to the Dogma of the Trinity. In: Collected Works, Vol. 11, 1969, p. $222-225$.

10. Petrušonis, V. Introdukuotieji kodai Kauno architektūroje. In: Urbanistika ir architektūra. XXVIII tomas, Nr. 3 priedas. Vilnius: Technika, 2004, p. 57-62.

11. Ricoeur, P. The Conflict of Interpretations: Essays in Hermeneutics. Allentown (USA): Northwestern University Press, 2007. 544 p.

12. Robinson, J. Architectural Research: Incorporating Myth and Science. In: Journal of Architectural Education, Vol. 44(1), 1990. p. 20-32.

13. Иванов, В. В. Эстетическое наследие древней и средневековой Индии. In: Литература и культура древней $и$ средневековой Индии. Москва: Наука, 1979, с. 6-35. 
14. Лотман, Ю. М., Успенский, Б. А. Миф - имя - культура. In: Семиотика: Труды по знаковым системам. Тарту, 1973, Том 6, с. 282-303.

15. Мамардашвили, М. К. Лекции по античной философии. Санкт-Петербург: Азбука, Азбука-Аттикус, 2012. $317 \mathrm{c}$.

16. Мамардашвили, М. К., Пятигорский, А. М. Символ и сознание. Москва: Языки русской культуры, 1997. $224 \mathrm{c}$.

17. Можейко, М. А. Поэтическое мышление. In: Новейший философский словарь. Сост. Грицанов А. А. Минск: Изд. В.М. Скакун, 1998. [available also at:] http://ponjatija.ru/node/6938

18. Раппапорт, А. Г. Методологические проблемы исследований архитектурной формы. In: Форма 6 архитектуре. Проблемы теории и методологии. Москва: Стройиздат, 1990, с. 8-90.

19. Федоров, В., Коваль, И. Мифосимволизм архитектуры. Москва: КомКнига, 2006. 208 с.

20. Шваллер де Любич, Р. О символе и символическом. In: Бадж Э. А., Нажеля Ж., Шваллер де Любич, Р. Легенды о египетских богах. Москва, Киев: Рефл-бук, 1997, с. 197-298.

21. Эко, У. Отсутствующая структура. Введение в семиологию. Санкт-Петербург: Симпозиум, 2006. 544 с.

22. Юнг, К. Психологические типы. Санкт-Петербург: Ювента Прогресс-Универс, 1995.716 с.

23. Ямпольский, М. Б. К символике водопада. In: Семиотика: Tруды по знаковым системам (Sign Systems Studies). K. Kull (ed). Тарту: Издательство Тартуского университета, 1987, Том 21, с. 26-41.

INFORMATION ABOUT AUTHOR:

Vytautas Petrušonis, Dr., is an Associate Professor in the Department of Architectural Fundamentals, Theory and Art of Vilnius Gediminas Technical University (VGTU). He obtained the degree of Doctor of the Humanities (architecture) from VGTU in 2005. His research interests are cultural identity of place, structural and typological features of architectural objects, architecture and psychology, ethics of architect, creative thinking of architect, metacritical analysis of architectural activity. Address: 26/1 Pylimo Str., Vilnius, 01132, Lithuania E-mail: vytautas.petrusonis@vgtu.lt

Kopsavilkums. Zināšanas par vietas simbolisko potenciālu (piemēram, pilsētas centrālais laukums) un šādu datu atspoguḷošana ir nozīmīga, lai labāk izprastu vietas kultūras vēsturi. Raksts atspoguḷo simboliskā potenciāla piemērus, izmantojot simbolisma kodu apkopojumu. Kodu vienības sastāv no 1) vietu veidojošo, identificēto, viegli atpazīstamo objektu nosaukumi un 2) kultūras idejas, kanonizētie raksturojumi šiem objektiem. Informācijas par vietu var palīdzēt to vadīt, ņemot vērā simbolisko potenciālu tikai gadījumā, kad kanonizētie raksturojumi ir ietverti datos. Raksts atklāj simboliskā potenciāla modeli Kauņas Vienotības laukumam (Vienybès aikštè) un tā tuvākajai apkārtnei, kas veidota pēc neatkarības atjaunošanas 1918. gadā. Simboliskā potenciāla pētījums tika veikts izmantojot teorētiskās metodes: abstrakciju, analoǵiju, vispārināšanu, pamatošanu (induktīvā, deduktīvā un abduktīvā) un sintēzi. 